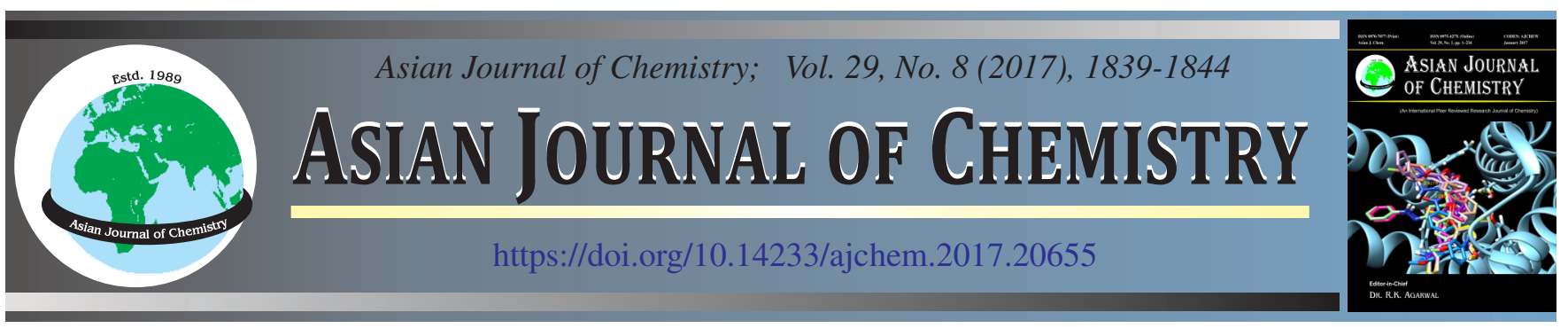

\title{
Synthesis of Novel Pyridyl-Based Schiff Base and Its Coordination Behaviour with Ruthenium(II) and Zinc(II)
}

Kamelah S. Al-Rashdi ${ }^{1}$, Naser E. Eltayeb ${ }^{2}$, Nada D. Al-Khathami ${ }^{1}$, Amal S. Basaleh ${ }^{1}$, Mutlaq Al-Jahdali ${ }^{1}$ and Bandar A. Babgi ${ }^{1,2, *}$

${ }^{1}$ Department of Chemistry, Faculty of Science, King Abdulaziz University, P.O. Box 80203, Jeddah 21589, Saudi Arabia ${ }^{2}$ Department of Chemistry, College of Science and Art, King Abdulaziz University, P.O. Box 344, Rabigh 21911, Saudi Arabia

*Corresponding author: Tel: +966 555563702; E-mail: bbabgi@kau.edu.sa

\section{INTRODUCTION}

Schiff Bases are organic class of compounds characterized with the azomethine (-CH=N-) bond. Due to the lone pair of the $s p^{2}$ nitrogen in the azomethine group, this organic class of compounds has a potential in coordination chemistry as ligands with high design flexibility and high functionality $[1,2]$. Transition metal complexes with Schiff bases have been of significant interest due to their antibacterial and antifungal activities [3-5]. Schiff base complexes can be tailored and designed as materials in many applications such as molecular sensing [6,7], optical switching [8], non-linear optics and photo-initiated processes [9]. Schiff bases are accessible by refluxing primary amines and aldehyde to form the carbinolamine moiety which undergoes a dehydration reaction to form the Schiff base. The dehydration step is reversible and hence the reaction sometimes is catalyzed by the addition of a weak acid or a weak base [10].

$p$-Toluidine has been used as a precursor in the synthesis of Schiff bases and showed good reactivity with aromatic aldehyde functionalized by a wide range of groups, ranging from strongly electron-withdrawing to strongly electron-releasing $[11,12]$. In this study, we are reporting our observations of the unusual reaction of pyridine-2-carboxaldehyde with $p$-toluidine. The resulted ligand was engaged with zinc(II) chloride in one experiment and with cis-bis(bipyridine)dichloro ruthenium(II) in another experiment to form two metal complexes.

\section{EXPERIMENTAL}

All the solvents were of HPLC grade and were used as received. Ammonium hexafluorophosphate, pyridine-2-carboxaldehyde (Alfa Asear), $p$-toluidine (Alfa asear) and zinc(II) chloride were purchased commercially and used as received. cis- $\mathrm{Ru}(\mathrm{bpy})_{2} \mathrm{Cl}_{2}$ was synthesized following the literature report [13].

Elemental analyses were conducted at King Abdulaziz University. Infrared spectra were recorded for powder samples of the complexes using a Bruker Alpha FT-IR; peaks are reported in $\mathrm{cm}^{-1}$. ${ }^{1} \mathrm{H} \mathrm{NMR}(600 \mathrm{MHz})$ spectra were recorded using a Bruker Avance III HD NMR spectrometer and ${ }^{31}$ P NMR spectra (121 MHz) were recorded using a Varian Mercury-300 FT NMR spectrometer. The spectra are referenced to residual chloroform $\left(7.26,{ }^{1} \mathrm{H}\right)$ or external $\mathrm{H}_{3} \mathrm{PO}_{4}\left(0.0 \mathrm{ppm},{ }^{31} \mathrm{P}\right)$. Highresolution electrospray ionization (ESI) mass spectra were recorded using an Agilent Q-TOF 6520 instrument; all mass spectrometry are reported as $m / z$.

Synthesis of pyridyl Schiff base (L): Pyridine-2-carboxaldehyde $(0.50 \mathrm{~g}, 4.6 \mathrm{mmol})$ and $p$-toluidine $(0.50 \mathrm{~g}, 4.6$ mmol) were stirred in $17 \mathrm{~mL}$ methanol at room temperature under $\mathrm{N}_{2}$ atmosphere for $30 \mathrm{~min}$. A beige precipitation was formed and the mixture was left under stirring for further $2 \mathrm{~h}$. The precipitation was collected by filtration and dried to afford a beige powder $(0.55 \mathrm{~g}, 61 \%)$. 
HR ESI MS $\left[\mathrm{C}_{26} \mathrm{H}_{22} \mathrm{~N}_{4}\right]^{+}$: Calcd. 390.1844, found 390.1844. Anal. calcd. for $\mathrm{C}_{26} \mathrm{H}_{22} \mathrm{~N}_{4}$ : C, 79.97; H, 5.68; N, $14.35 \%$, found: C, $80.31 ; \mathrm{H}, 5.79 ; \mathrm{N}, 13.92 \%$. IR (solid): 1625 and $1583 \mathrm{~cm}^{-1}$ v (aromatic $\mathrm{C}=\mathrm{C}$ and $\mathrm{C}=\mathrm{N}), 1565 \mathrm{~cm}^{-1} \mathrm{v}(-\mathrm{HC}=\mathrm{N}) .{ }^{1} \mathrm{H}$ NMR $\delta$ : 2.48 (s, 6H, $\left.\mathrm{CH}_{3}\right), 7.11\left(\mathrm{~d}, 2 \mathrm{H}, \mathrm{H}_{6}\right), 7.38\left(\mathrm{~m}, 2 \mathrm{H}, \mathrm{H}_{3}\right), 7.49$ (dd, 2H, $\left.\mathrm{H}_{7}\right), 7.52\left(\mathrm{~S}, 2 \mathrm{H}, \mathrm{H}_{8}\right), 7.82\left(\mathrm{t}, 2 \mathrm{H}, \mathrm{H}_{2}\right), 8.28$ (d, 2H, $\left.\mathrm{H}_{4}\right), 8.59\left(\mathrm{~s}, 2 \mathrm{H}, \mathrm{H}_{5}\right), 8.70\left(\mathrm{~d}, 2 \mathrm{H}, \mathrm{H}_{1}\right) \cdot{ }^{13} \mathrm{C}$ NMR $\delta: 18.06$ $\left(\mathrm{CH}_{3}\right), 117.95\left(\mathrm{C}_{6}\right), 121.69\left(\mathrm{C}_{4}\right), 125.03$ and $125.30\left(\mathrm{C}_{2}\right.$ and $\left.\mathrm{C}_{7}\right), 128.94\left(\mathrm{C}_{8}\right), 132.96\left(\mathrm{C}_{3}\right), 136.64\left(\mathrm{C}_{11}\right), 138.89\left(\mathrm{C}_{12}\right)$, 149.05 and $149.61\left(\mathrm{C}_{1}\right.$ and $\left.\mathrm{C}_{10}\right), 154.90\left(\mathrm{C}_{9}\right), 159.57\left(\mathrm{C}_{5}\right)$.

Reaction of $\mathrm{L}$ with cis $-\mathbf{R u}(\mathbf{b p y})_{2} \mathbf{C l}_{\mathbf{2}}(\mathbf{R u}-\mathbf{L})$ : cis- $\mathrm{Ru}(\mathrm{bpy})_{2} \mathrm{Cl}_{2}$ $(0.20 \mathrm{~g}, 0.38 \mathrm{mmol})$ and $\mathrm{L}(0.15 \mathrm{~g}, 0.38 \mathrm{mmol})$ were refluxed in a mixture of ethanol $(16 \mathrm{~mL})$ and water $(4 \mathrm{~mL})$ under nitrogen atmosphere for $8 \mathrm{~h}$. The reaction mixture was cooled down and $\mathrm{NH}_{4} \mathrm{PF}_{6}(0.13 \mathrm{~g}, 0.77 \mathrm{mmol})$ was added with $15 \mathrm{~mL}$ water, leading to form a red precipitate. The precipitate was collected by filtration, washed several times with water and dried, affording the Ru-L as a dark red powder $(0.20 \mathrm{~g}, 79 \%)$. HR ESI MS $\left[\mathrm{C}_{26} \mathrm{H}_{20} \mathrm{~N}_{5} \mathrm{O}_{2} \mathrm{Ru}\right]^{+}$: calcd. 536.0660, found 536.0649. Anal. calcd. for $\mathrm{C}_{26} \mathrm{H}_{20} \mathrm{~F}_{6} \mathrm{~N}_{5} \mathrm{O}_{2} \mathrm{PRu}$ : C, 45.89; H, 4.09; N, $11.62 \%$, found: C, 45.43; H, 4.32; N, $11.27 \%$. IR (solid): $1603 \mathrm{~cm}^{-1} v($ aromatic $\mathrm{C}=\mathrm{C}$ and $\mathrm{C}=\mathrm{N}), 1658 \mathrm{~cm}^{-1} v(\mathrm{O}-\mathrm{C}=\mathrm{O})$.

Reaction of $\mathrm{L}$ with zinc(II) chloride (Zn-L): Zinc chloride $(0.02 \mathrm{~g}, 0.15 \mathrm{mmol})$ and $\mathrm{L}(0.02 \mathrm{~g}, 0.05 \mathrm{mmol})$ were refluxed in methanol $(10 \mathrm{~mL})$ under normal conditions for $1 \mathrm{~h}$. The reaction mixture was allowed to cool down and left to evaporate over 2 days, affording red crystals. The crystals were washed with water several times to give $\mathrm{Zn}-\mathrm{L}$ as a red crystals (0.01 g, $50 \%$ ). HR ESI MS $\left[\mathrm{C}_{20} \mathrm{H}_{19} \mathrm{Cl}_{2} \mathrm{~N}_{3} \mathrm{Zn}\right]^{+}$: calcd. 435.0247, found 435.0246. Anal. calcd. for $\mathrm{C}_{20} \mathrm{H}_{19} \mathrm{Cl}_{2} \mathrm{~N}_{3} \mathrm{Zn}$ : C, 54.88; H, 4.38; N, $9.60 \%$, found: C, 54.69; H, 4.32; N, 9.74\%. IR (solid): $1606 \mathrm{~cm}^{-1} \mathrm{v}($ aromatic $\mathrm{C}=\mathrm{C}$ and $\mathrm{C}=\mathrm{N}), 3312$, $3129 \mathrm{~cm}^{-1} \mathrm{v}\left(\mathrm{NH}_{2}\right)$.<smiles>Cc1cc(-c2c(C)c(C)[n+](C=Nc3ccccn3)c(C)c2C)ccc1N=Cc1ccccn1</smiles>

Fig. 1. NMR labeling for the ligand (L)

Crystallography of L, Ru-L and Zn-L: The crystals of $\mathrm{L}, \mathrm{Ru}-\mathrm{L}$ and $\mathrm{Zn}-\mathrm{L}$ were crystallized from methanol by slow evaporation. D8 QUEST Bruker Diffractometer, equipped with graphite-monochromatic $\mathrm{MoK}_{\alpha}$ radiation was used for data collection. The data collection was preceded using APEX3 software [15] at $293 \mathrm{~K}$. The structure solution was performed using SHELXS-2014 [14-16] and refined by full-matrix leastsquares methods on $\mathrm{F}^{2}$ using SHELXL-2014 [15-17] in-built with APEX3 software [17]. All non-hydrogen atoms were refined anisotropically by full-matrix least squares methods.

TABLE-1

DATA COLLECTION AND STRUCTURE REFINEMENT FOR L, Ru-L AND Zn-L

\begin{tabular}{|c|c|c|c|}
\hline Identification code & $\mathrm{L}$ & $\mathrm{Ru}-\mathrm{L}$ & Zn-L \\
\hline Chemical formula & $\mathrm{C}_{26} \mathrm{H}_{22} \mathrm{~N}_{4}$ & $\mathrm{C}_{26} \mathrm{H}_{20} \mathrm{~F}_{6} \mathrm{~N}_{5} \mathrm{O}_{2} \mathrm{PRu}$ & $\mathrm{C}_{20} \mathrm{H}_{19} \mathrm{Cl}_{2} \mathrm{~N}_{3} \mathrm{Zn}$ \\
\hline Formula weight & $390.48 \mathrm{~g} / \mathrm{mol}$ & $680.51 \mathrm{~g} / \mathrm{mol}$ & $437.65 \mathrm{~g} / \mathrm{mol}$ \\
\hline Temperature & 293(2) K & 293(2) K & 293(2) K \\
\hline Wavelength & $0.71073 \AA$ & $0.71073 \AA$ & $0.71073 \AA$ \\
\hline Crystal system & Triclinic & Monoclinic & Triclinic \\
\hline Space group & P-1 & P 1 21/n 1 & P-1 \\
\hline \multirow[t]{3}{*}{ Unit cell dimensions } & $a=10.57(2) \AA, \alpha=110.77(3)^{\circ}$ & $\mathrm{a}=14.260(12) \AA, \alpha=90^{\circ}$ & $\mathrm{a}=7.43(2) \AA, \alpha=93.20(3)^{\circ}$ \\
\hline & $\mathrm{b}=11.59(2) \AA, \beta=91.61(4)^{\circ}$ & $\mathrm{b}=10.957(13) \AA, \beta=107.61(2)^{\circ}$ & $\mathrm{b}=8.81(2) \AA, \beta=91.67(4)^{\circ}$ \\
\hline & $\mathrm{c}=13.23(3) \AA, \gamma=99.09(3)^{\circ}$ & $\mathrm{c}=16.658(17) \AA, \gamma=90^{\circ}$ & $\mathrm{c}=16.37(4) \AA, \gamma=110.71(3)^{\circ}$ \\
\hline Volume & 1490.(5) $\AA^{3}$ & 2481.(4) $\AA^{3}$ & 999.(4) $\AA^{3}$ \\
\hline $\mathrm{Z}$ & 2 & 4 & 2 \\
\hline Density (calculated) & $1.307 \mathrm{~g} / \mathrm{cm}^{3}$ & $1.822 \mathrm{~g} / \mathrm{cm}^{3}$ & $1.454 \mathrm{~g} / \mathrm{cm}^{3}$ \\
\hline Absorption coefficient & $0.079 \mathrm{~mm}^{-1}$ & $0.779 \mathrm{~mm}^{-1}$ & $1.504 \mathrm{~mm}^{-1}$ \\
\hline $\mathrm{F}(000)$ & 618 & 1360 & 448 \\
\hline Index ranges & $\begin{array}{l}-12<=\mathrm{h}<=12,-13<=\mathrm{k}<=13,- \\
15<=\mathrm{l}<=15\end{array}$ & $\begin{array}{l}-17<=\mathrm{h}<=17,-13<=\mathrm{k}<=13,- \\
20<=\mathrm{l}<=20\end{array}$ & $\begin{array}{l}-8<=\mathrm{h}<=8,-10<=\mathrm{k}<=10,- \\
19<=\mathrm{l}<=19\end{array}$ \\
\hline Reflections collected & 40718 & 77785 & 26959 \\
\hline Independent reflections & $5467[\mathrm{R}($ int $)=0.0515]$ & $4608[\mathrm{R}(\mathrm{int})=0.0372]$ & $3622[\mathrm{R}(\mathrm{int})=0.0898]$ \\
\hline Refinement method & Full-matrix least-squares on $\mathrm{F}^{2}$ & Full-matrix least-squares on $\mathrm{F}^{2}$ & Full-matrix least-squares on $\mathrm{F}^{2}$ \\
\hline Refinement program & SHELXL-2014/7 (Sheldrick, 2014) & SHELXL-2014/7 (Sheldrick, 2014) & SHELXL-2014/7 (Sheldrick, 2014) \\
\hline Function minimized & $\Sigma \mathrm{w}\left(\mathrm{F}_{\mathrm{o}}^{2}-\mathrm{F}_{\mathrm{c}}^{2}\right)^{2}$ & $\sum \mathrm{w}\left(\mathrm{F}_{\mathrm{o}}^{2}-\mathrm{F}_{\mathrm{c}}^{2}\right)^{2}$ & $\sum \mathrm{w}\left(\mathrm{F}_{\mathrm{o}}^{2}-\mathrm{F}_{\mathrm{c}}^{2}\right)^{2}$ \\
\hline Data/restraints/parameters & $5467 / 0 / 409$ & $4608 / 0 / 370$ & $3622 / 0 / 245$ \\
\hline Goodness-of-fit on $\mathrm{F}^{2}$ & 1.017 & 1.030 & 1.081 \\
\hline \multirow[t]{4}{*}{ Final $\mathrm{R}$ indices } & 3989 data; $\mathrm{I}>2 \sigma(\mathrm{I})$ & 4048 data; $\mathrm{I}>2 \sigma(\mathrm{I})$ & 2707 data; $\mathrm{I}>2 \sigma(\mathrm{I})$ \\
\hline & $\mathrm{R} 1=0.0471, \mathrm{wR} 2=0.1061$ & $\mathrm{R} 1=0.0327, w \mathrm{R} 2=0.0775$ & $\mathrm{R} 1=0.0475, \mathrm{wR} 2=0.0863$ \\
\hline & All data & All data & All data \\
\hline & $\mathrm{R} 1=0.0744, \mathrm{wR} 2=0.1176$ & $\mathrm{R} 1=0.0397, \mathrm{wR} 2=0.0812$ & $\mathrm{R} 1=0.0770, \mathrm{wR} 2=0.0952$ \\
\hline Weighting scheme & $\begin{array}{l}\mathrm{w}=1 /\left[\sigma^{2}\left(\mathrm{~F}_{\mathrm{o}}^{2}\right)+(0.0527 \mathrm{P})^{2}+0.6848 \mathrm{P}\right] \\
\text { where } \mathrm{P}=\left(\mathrm{F}_{\mathrm{o}}^{2}+2 \mathrm{~F}_{\mathrm{c}}^{2}\right) / 3\end{array}$ & $\begin{array}{l}\mathrm{w}=1 /\left[\sigma^{2}\left(\mathrm{~F}_{\mathrm{o}}^{2}\right)+(0.0344 \mathrm{P})^{2}+6.5902 \mathrm{P}\right] \\
\text { where } \mathrm{P}=\left(\mathrm{F}_{\mathrm{o}}^{2}+2 \mathrm{~F}_{\mathrm{c}}^{2}\right) / 3\end{array}$ & $\begin{array}{l}\mathrm{w}=1 /\left[\sigma^{2}\left(\mathrm{~F}_{\mathrm{o}}^{2}\right)+(0.0181 \mathrm{P})^{2}+1.8431 \mathrm{P}\right] \\
\text { where } \mathrm{P}=\left(\mathrm{F}_{\mathrm{o}}^{2}+2 \mathrm{~F}_{\mathrm{c}}^{2}\right) / 3\end{array}$ \\
\hline
\end{tabular}


APEX3 software [17] is used to draw figures. The molecules has only aromatic hydrogen atoms which were positioned geometrically and treated as riding atoms with $\mathrm{C}-\mathrm{H}=0.93 \AA$ and Uiso $(\mathrm{H})=1.2 \mathrm{Ueq}(\mathrm{C})$ carbon atoms. The crystal data (Table-1) and Data collection with structure refinement details for $\mathrm{L}, \mathrm{Ru}-\mathrm{L}$ and $\mathrm{Zn}-\mathrm{L}$ listed in Table-1. The CIF files are obtainable free of charge from Cambridge crystallographic Data Center (CCDC) under CCDC number 1526413 for L, 1526414 for Ru-L and 1526415 for $\mathrm{Zn}-\mathrm{L}$.

\section{RESULTS AND DISCUSSION}

In our attempts to obtain a series of ligands derived from pyridine-2-carboxaldehyde, unusual reaction was encountered with $p$-toluidine. The methyl group isomerization and the dimerization (biphenyl formation) seems to proceed very fast after the Schiff base formation at room temperature in few minutes (Scheme-I). We tried to shorten the time, run the reaction in dark and in an ice bath, hoping to prevent the further reactions after the Schiff base formation. However, we could not observe any traces of the Schiff base (monomer).

Isomerization of alkyl and aryl groups in arene rings has been reported in literatures [18-21] and such reaction has been used in many industrial processes including the conversion of mixed xylene to $p$-xylene [22]. Many reports highlighted the importance of temperature and/or the presence of acid to catalyze the process [18-22]. In present case, the pyridine-2carboxaldehyde $(99 \%$ ) contains $0.5 \%$ of the free acid and it is possibly the source of $\mathrm{H}^{+}$that catalyze the isomerization of the methyl group (steps 1, 2 and 3 in Scheme-II).

The dimerization process can only proceeds by the oxidative coupling to give the biphenyl system [23]. However, this reaction requires a catalyst to promote the coupling unless the phenyl ring is reasonably electron rich (steps 4, 5 and 6 in Scheme-II) [24]. The methyl group on the ring is believed to be of huge importance in driving the biphenyl formation as the analogue Schiff base derived from the reaction of benzaldehyde and pyridine-2-carboxaldehyde does not proceed the dimerization [25]. More work is ongoing to gain a better understanding of the nature of the reaction of pyridine-2carboxaldehyde with variant aromatic amine and the reactivity of the resulted Schiff bases.

The obtained dimerized Schiff base has two coordinating bidentate sites which encouraged us to try the preparation of bimetallic systems. Although, we tried many metal salts and some organometallic centers, but only two metal complexes were isolated and identified by X-ray crystallography (Scheme-I). The steric hindrance in the ligand slow down its coordination and the presence of metal ion with water seem to promote the oxidation of one of the azomethine bond [26]. The ruthenium(II) favours the coordination of the pyridine-2carboxylic acid resulted from the azomethine oxidation due to the steric bulkiness of the pyridine-2-Schiff base. The ruthenium(II) complexes reported previously through the reaction of cis-[Ru(bpy) $\left.{ }_{2} \mathrm{Cl}_{2}\right]$ with (1-Methyl-1H-imidazol-2-yl)pyridin-2-yl ketone as the ligand underwent an oxidation reaction before the coordination [27]. Ruthenium(II) complexes with carboxylate ligands are of interest because of their electrochemical and spectroscopic behaviour [28,29]. Zinc(II) can be coordinated to the pyridine-2-Schiff base moiety because of it is smaller ion radius compared to ruthenium and the absence of co-ligands which contributes to the stericdemand in the ruthenium center. The reaction of zinc(II) with

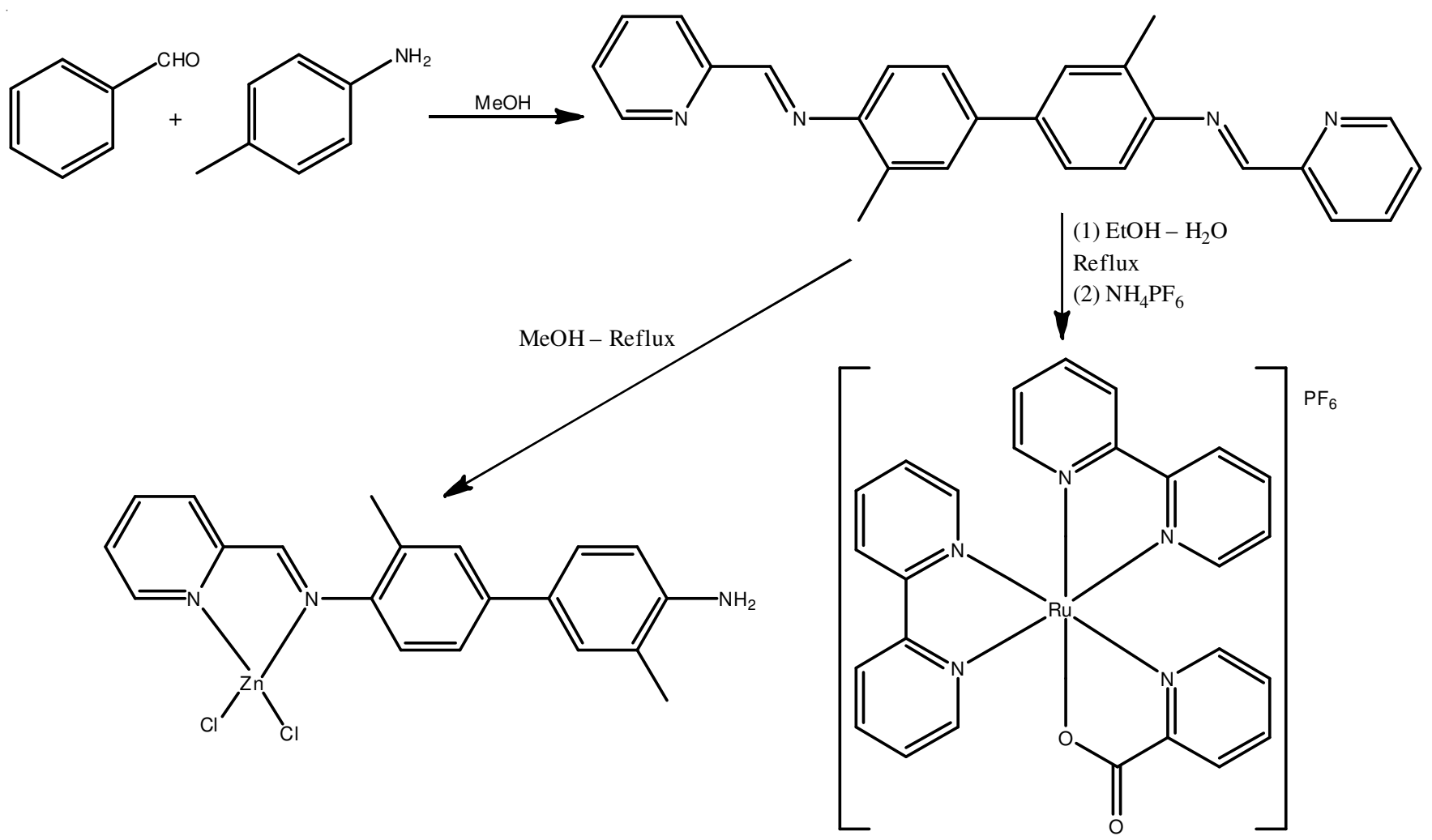

Scheme-I: Synthesis of the Schiff base ligand with their reaction with ruthenium(II) and zinc(II) 


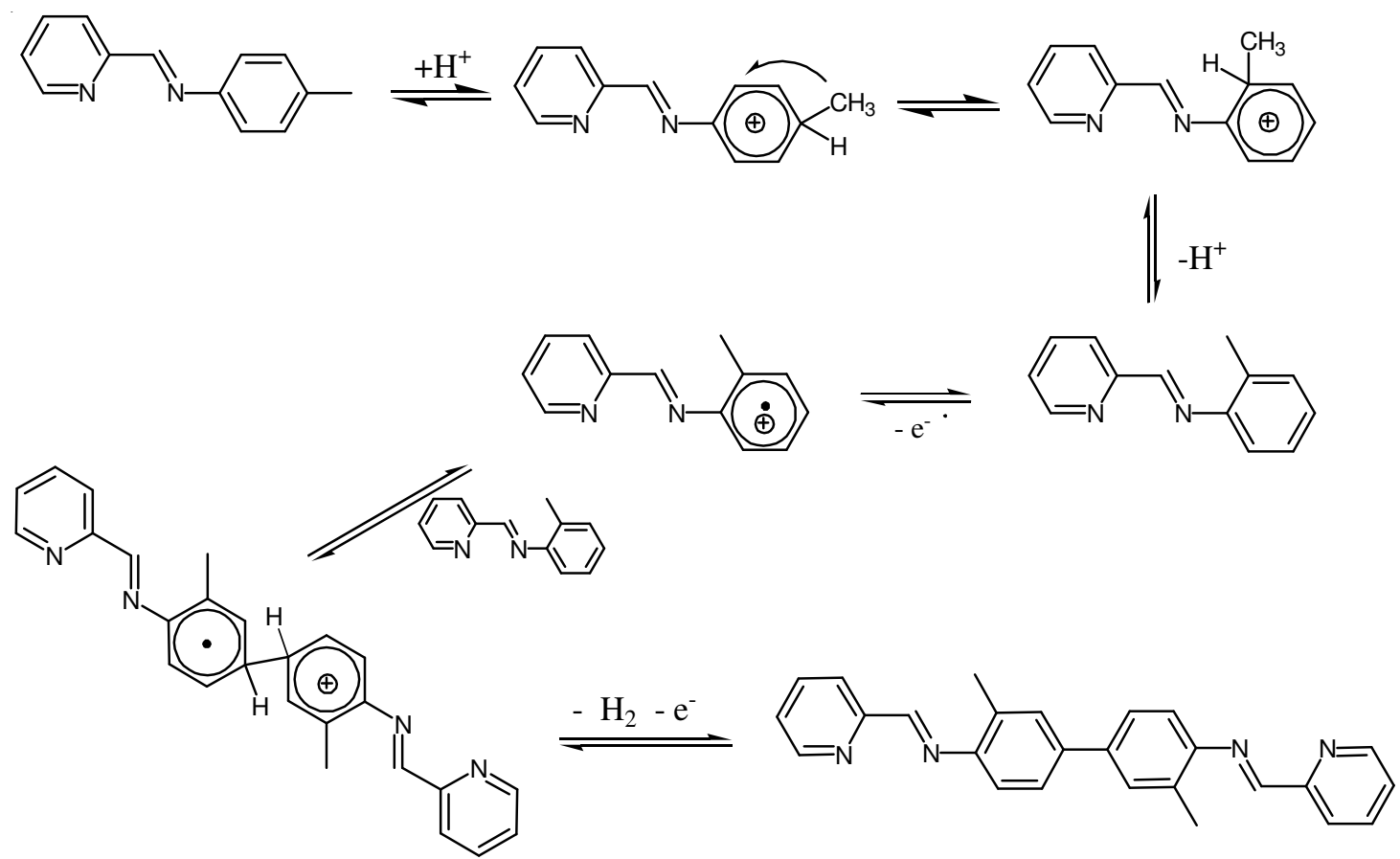

Scheme-II: Suggested mechanism for the ligand formation

multidentate $\mathrm{N}$-based ligands provides coordination complexes with tetrahedral [30,31], trigonal bipyrimidal [31,32] and octahedral geometries [32]. The zinc coordinates to one site of pyridyl- $\mathrm{CH}=\mathrm{N}$ while the second $\mathrm{CH}=\mathrm{N}$ undergoes an oxidation reaction to produce the amino group.

Crystallography of (E)-N-(3,3'-dimethyl-4'-(((E)-(5methylpyridin-2-yl) methylene)amino)-[1,1'-biphenyl]-4yl)-1-(pyridin-2-yl)methanimine $(\mathrm{L})$ : The structure of $(\mathrm{E})$ N-(3,3'-dimethyl-4'-(((E)-(5-methylpyridin-2-yl)methylene)amino)-[1,1'-biphenyl]-4-yl)-1-(pyridin-2-yl)methanimine, $\mathrm{C}_{26} \mathrm{H}_{22} \mathrm{~N}_{6}$, has triclinic (P-1) symmetry. The structure displays $\mathrm{C}-\mathrm{H} \cdots \mathrm{N}$ intramolecular and intermolecular hydrogen bonds. The molecule is consists of two (E)-1-(pyridin-2-yl)-N-(o-tolyl)methanimine connected in para-position. The dihedral angles between the six-membered ring Pyridyl N1/C1-C5 and others six-membered rings $\mathrm{C} 22-\mathrm{C} 26 / \mathrm{N} 4, \mathrm{C} 7-\mathrm{C} 12$ and $\mathrm{C} 14-\mathrm{C} 20$ are 37.04(9), 35.80(9) and 61.09(9), respectively. The torsion angles C7-N2-C6-C5 = 179.95(15) and C22-C21-N3-C17 = -177.82(15) which connected the pyridine and N-o-tolylmethanimine moieties. Fig. 2 displays the molecule structure of $\mathrm{L}$ and Table-2 displays some selected data for the compound.

Crystallography of Ru-L: The crystal structure of the complex is shown Fig. 3. The asymmetric unit of the title compound, $\left[\mathrm{Ru}\left(\mathrm{C}_{10} \mathrm{H}_{8} \mathrm{~N}_{2}\right)_{2}-\left(\mathrm{C}_{6} \mathrm{H}_{4} \mathrm{NO}_{2}\right)\right] \mathrm{PF}_{6}$, contains a monomeric [Ru(bpy)2(py-COO)] cation $\{$ bpy is 2,2'-bipyridine and py-COO is pyridine-2-carboxylate and one hexafluorophos-

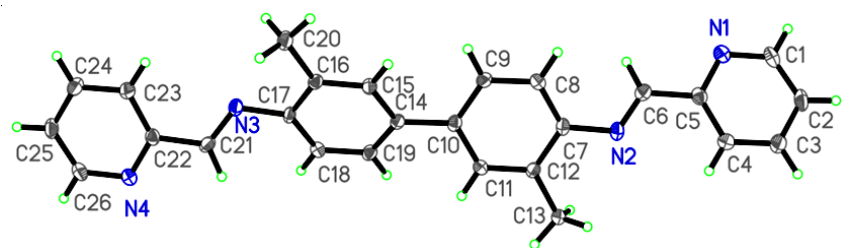

Fig. 2. Molecular structure of the $\mathbf{L}$ compound, shown with $50 \%$ probability displacement ellipsoids and the atom-numbering scheme

\begin{tabular}{|c|c|c|c|}
\hline \multicolumn{4}{|c|}{$\begin{array}{c}\text { TABLE-2 } \\
\text { SELECTED BOND LENGTHS AND ANGLES IN L COMPLEX }\end{array}$} \\
\hline \multicolumn{2}{|c|}{ Bond length $(\AA)$} & \multicolumn{2}{|c|}{ Bond angles and Torsion angles } \\
\hline N2-C6 & $1.272(3)$ & C21-N3-C17 & $120.60(19)^{\circ}$ \\
\hline N3-C21 & $1.272(3)$ & C6-N2-C7 & $119.65(19)^{\circ}$ \\
\hline $\mathrm{N} 2-\mathrm{C} 7$ & $1.409(3)$ & $\mathrm{C} 26-\mathrm{N} 4-\mathrm{C} 22$ & $116.8(2)^{\circ}$ \\
\hline N3-C17 & $1.415(3)$ & $\mathrm{C} 1-\mathrm{N} 1-\mathrm{C} 5$ & $116.86(19)^{\circ}$ \\
\hline $\mathrm{C} 10-\mathrm{C} 14$ & $1.482(3)$ & $\mathrm{N} 1-\mathrm{C} 5-\mathrm{C} 4$ & $122.69(17)^{\circ}$ \\
\hline - & - & C11-C10-C14-C15 & $155.64(17)^{\circ}$ \\
\hline
\end{tabular}

phate anion (Fig. 3). The ruthenium(II) ion is in a distorted octahedral environment coordinated by two bpy ligands and one py-COO ligand, the $\mathrm{Ru}-\mathrm{N}$ and $\mathrm{Ru}-\mathrm{O}$ bond lengths as follows: Ru1-N1 = 2.023(8) $\AA$, Ru1-N2 = 2.011(8) $\AA$, Ru1$\mathrm{N} 3=2.060(8) \AA, \mathrm{Ru} 1-\mathrm{N} 4=2.043(8) \AA, \mathrm{Ru} 1-\mathrm{N} 5=2.071(8)$ $\AA$ and $\mathrm{Ru} 1-\mathrm{O} 1=2.094(7) \AA$. The ligands bite angles are N1Ru1-N2 $=78.94(12)^{\circ}$ to N3-Ru1-N4 $=79.00(10)^{\circ}$ and N5$\mathrm{Ru} 1-\mathrm{O} 1=78.88(10)^{\circ}$ to N2-Ru1-O1 = 170.7(3) ${ }^{\circ}$. Table-3 displays some selected data for ruthenium complex. The crystal structure data is in agreement with the data reported previously for the same complex synthesized via two different routes [27].

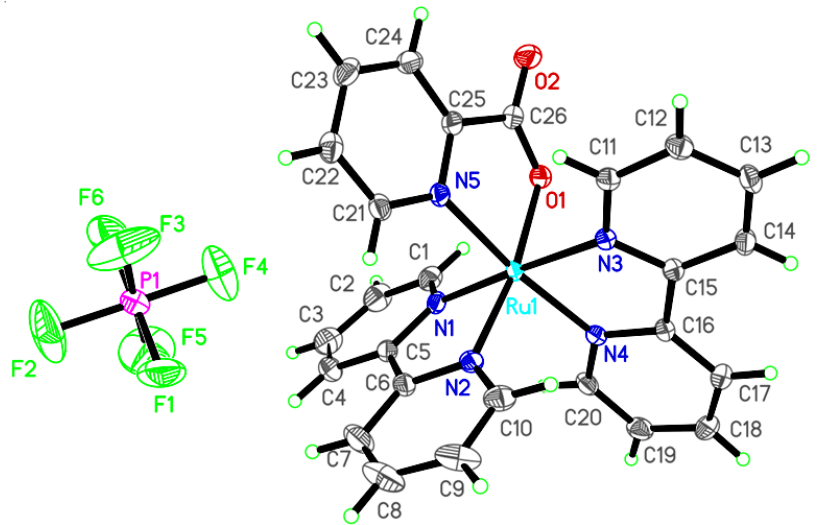

Fig. 3. Molecular structure of Ru-L complex, shown with $50 \%$ probability displacement ellipsoids and the atom-numbering scheme 
TABLE-3

SELECTED BOND LENGTHS AND ANGLES IN Ru-L COMPLEX

\begin{tabular}{cclc}
\hline \multicolumn{2}{c}{ Bond length $(\AA)$} & \multicolumn{2}{c}{ Bond angles } \\
\hline Ru1-N1 & $2.024(3)$ & N2-Ru1-O1 & $171.06(9)^{\circ}$ \\
Ru1-N2 & $2.017(3)$ & N5-Ru1-O1 & $78.88(10)^{\circ}$ \\
Ru1-N3 & $2.054(3)$ & N2-Ru1-N1 & $78.94(12)^{\circ}$ \\
Ru1-N4 & $2.039(3)$ & N1-Ru1-N3 & $176.22(9)^{\circ}$ \\
Ru-N5 & $2.051(3)$ & N4-Ru1-N3 & $79.00(10)^{\circ}$ \\
Ru1-O1 & $2.092(2)$ & N4-Ru1-N5 & $173.08(9)^{\circ}$ \\
\hline
\end{tabular}

Crystallography of Zn-L: A view of the molecular structure of the title compound is shown in Fig. 4. The $\mathrm{Zn}$ (II) ion is coordinated by two chloride ions and by the bidentate NN site of the ligand. The $\mathrm{Zn}-\mathrm{N} 2$ bond is longer than that of Zn-N1 (2.059(5) and 2.096(5) $\AA$, respectively), due to the strong steric effect of the methyl group while the $\mathrm{Zn}-\mathrm{Cl}$ bonds are almost identical. The coordination environment of $\mathrm{Zn}$ (II) ion can be described as trigonal pyramidal, $\tau=0.81$ (Extreme Forms: 0.00 for SQP and 1.00 for TET; 0.85 for TRP) [33]. Although, $\mathrm{Zn}$ (II) complexes normally adopt tetrahedral geometry $[30,31]$ or less commonly trigonal bipyrimidal $[31,32]$ due to the lack of any ligand field stabilization energy of the $d^{10}$ metal, the bulkiness of the methyl group forces the unusual geometry of the complex. The bond angles around the $\mathrm{Zn}(\mathrm{II})$ ion are $\mathrm{N} 1-\mathrm{Zn} 1-\mathrm{N} 2=81.3(2), \mathrm{N} 1-\mathrm{Zn} 1-\mathrm{Cl} 2=$ 116.87(16), N2-Zn1-Cl2 = 105.57(11), N1-Zn1-Cl1 = 108.68(19), N2-Zn1-Cl1 = 123.16(16) and Cl2-Zn1-Cl1 = $116.74(9)^{\circ}$. Table-4 illustrates some selected bond lengths and angles for the zinc compound.

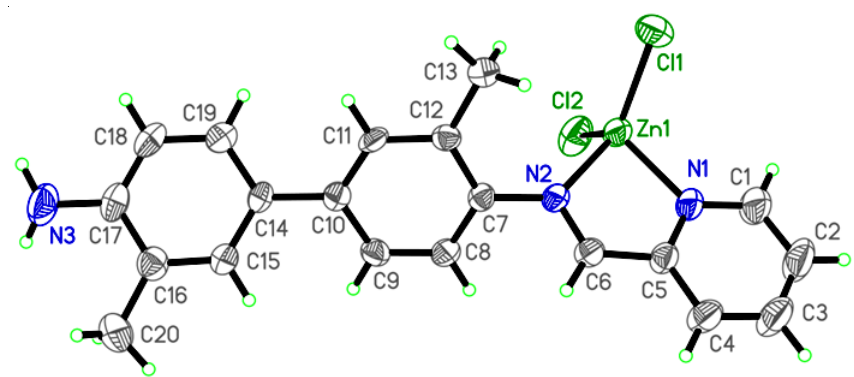

Fig. 4. Molecular structure of $\mathrm{Zn}-\mathrm{L}$ complex shown with $50 \%$ probability displacement ellipsoids and atom-numbering scheme

TABLE-4

SELECTED BOND LENGTHS AND ANGLES IN Zn-1 COMPLEX

Bond length $(\AA)$

\begin{tabular}{lllc} 
Zn1-Cl1 & $2.212(5)$ & $\mathrm{Cl} 2-\mathrm{Zn} 1-\mathrm{Cl} 1$ & $116.74(9)^{\circ}$ \\
Zn1-Cl2 & $2.208(5)$ & $\mathrm{N} 2-\mathrm{Zn} 1-\mathrm{Cl} 1$ & $123.16(16)^{\circ}$ \\
Zn1-N1 & $2.059(5)$ & $\mathrm{N} 1-\mathrm{Zn} 1-\mathrm{Cl} 1$ & $108.67(19)^{\circ}$ \\
Zn1-N2 & $2.096(5)$ & $\mathrm{N} 2-\mathrm{Zn} 1-\mathrm{Cl} 2$ & $105.57(11)^{\circ}$ \\
N2-C6 & $1.275(5)$ & $\mathrm{N} 1-\mathrm{Zn} 1-\mathrm{Cl} 2$ & $116.87(16)^{\circ}$ \\
$\mathrm{C} 5-\mathrm{C} 6$ & $1.467(6)$ & $\mathrm{N} 1-\mathrm{Zn} 1-\mathrm{N} 2$ & $81.3(2)^{\circ}$ \\
\hline
\end{tabular}

\section{Conclusion}

The high reactivity of Schiff base product of $p$-toluidine with pyridine-2-carboxaldehyde was observed, leading to methyl group immigration to ortho-position followed by the dimerization reaction to form biphenyl system, forming the highly conjugated ligand with two bidentate coordination sites. The coordination behaviour of the Schiff base was examined against many metal salts and some organometallic centers. Two metal complexes were only isolated and identified by Xray crystallography for ruthenium(II) and zinc(II), showing that metals promote the catalyzed oxidation of the azomethine bond in case of the ruthenium center followed by the coordination of ruthenium center to pyridine-2-carboxylic acid while zinc is coordinated to NN site on the ligand followed by the catalyzed oxidation. The crystal structure of zinc(II) complex showed trigonal pyramidal geometry, enforced by the methyl steric hindrance. Further studies are ongoing to explore the behaviour of the ligand with different metal centers and to synthesize more ligands derived from pyridine-2-carboxaldehyde.

\section{ACKNOWLEDGEMENTS}

One of the authors, Ms. K.S. Al-Rashdi acknowledge to King Abdulaziz City for Science and Technology (KACST) for their generous funding for her master degree project.

\section{REFERENCES}

1. A. Pui, T. Malutan, L. Tataru, C. Malutan, D. Humelnicu and G. Carja, Polyhedron, 30, 2127 (2011);

https://doi.org/10.1016/j.poly.2011.05.029.

2. P. Tyagi, S. Chandra, B.S. Saraswat and D. Yadav, Spectrochim. Acta A, 145, 155 (2015);

https://doi.org/10.1016/j.saa.2015.03.034.

3. G.B. Bagihalli, P.G. Avaji, S.A. Patil and P.S. Badami, Eur. J. Med. Chem., 43, 2639 (2008);

https://doi.org/10.1016/j.ejmech.2008.02.013.

4. R.S. Hoonur, B.R. Patil, D.S. Badiger, R.S. Vadavi, K.B. Gudasi, P.R. Dandawate, M.M. Ghaisas, S.B. Padhye and M. Nethaji, Eur. J. Med. Chem., 45, 2227 (2010); https://doi.org/10.1016/i.ejmech.2010.01.072.

5. K.A. Khadra, S. Mizyed, D. Marji, S.F. Haddad, M. Ashram and A. Foudeh, Spectrochim. Acta A, 136, 1869 (2015); https://doi.org/10.1016/j.saa.2014.10.100.

6. D. Ma, P. Ma, D.S. Chan, K. Leung, H. He and C. Leung, Coord. Chem. Rev., 256, 3087 (2012);

https://doi.org/10.1016/j.ccr.2012.07.005.

7. B. Babgi and A. Alzahrani, J. Fluoresc., 26, 1415 (2016); https://doi.org/10.1007/s10895-016-1833-0.

8. K.B. Manjunatha, R. Dileep, G. Umesh and B.R. Bhat, Mater. Lett., 105, 173 (2013); https://doi.org/10.1016/j.matlet.2013.03.076.

9. J.M. Floyd, G.M. Gray, A.G. VanEngen Spivey, C.M. Lawson, T.M. Pritchett, M.J. Ferry, R.C. Hoffman and A.G. Mott, Inorg. Chim. Acta, 358, 3773 (2005); https://doi.org/10.1016/j.ica.2005.05.009.

10. E.H. Cordes and W.P. Jencks, J. Am. Chem. Soc., 85, 2843 (1963); https://doi.org/10.1021/ja00901a037.

11. S. Patil, S.D. Jadhav and U.P. Patil, Arch. Appl. Sci. Res., 4, 1074 (2012).

12. L. Guofa, N. Chongwu, L. Bin and M. Kunyuan, Polyhedron, 9, 2019 (1990); https://doi.org/10.1016/S0277-5387(00)84030-9.

13. B.P. Sullivan, D.J. Salmon and T.J. Meyer, Inorg. Chem., 17, 3334 (1978); https://doi.org/10.1021/ic50190a006.

14. G.M. Sheldrick, Acta Crystallogr. A, 64, 112 (2008); https://doi.org/10.1107/S0108767307043930.

15. G.M. Sheldrick, Acta Crystallogr. C, 71, 3 (2015); https://doi.org/10.1107/S2053229614024218.

16. A.L. Spek, Acta Crystallogr. C, 71, 9 (2015); https://doi.org/10.1107/S2053229614024929.

17. Bruker, APEX3, SAINT and SADABS. Bruker AXS Inc., Madison, Wisconsin, USA (2016).

18. J. Norris and H. Turner, J. Am. Chem. Soc., 61, 2128 (1939); https://doi.org/10.1021/ja01877a044.

19. J. Norris and G. Vaala, J. Am. Chem. Soc., 61, 2131 (1939); https://doi.org/10.1021/ja01877a045. 
20. A. Ajaz, E.C. McLaughlin, S.L. Skraba, R. Thamatam and R.P. Johnson, J. Org. Chem., 77, 9487 (2012); https://doi.org/10.1021/jo301848g.

21. K. Beschmann and L. Riekert, J. Catal., 141, 548 (1993); https://doi.org/10.1006/jcat.1993.1163.

22. K. Griesbaum, A. Behr, D. Biedenkapp, H.-W. Voges, D. Garbe, C. Paetz, C. Collin, D. Mayer and H. Höke, Hydrocarbons, Ullmann's Encyclopedia of Industrial Chemistry (2000).

23. S. Mukhopadhyay, G. Rothenberg, G. Lando, K. Agbaria, M. Kazanci and Y. Sasson, Adv. Synth. Catal., 343, 455 (2001); https://doi.org/10.1002/1615-4169(200107)343:5<455::AIDADSC455>3.0.CO $\div 2-\mathrm{O}$

24. M. Grzybowski, K. Skonieczny, H. Butenschön and D.T. Gryko, Angew. Chem. Int. Ed., 52, 9900 (2013); https://doi.org/10.1002/anie.201210238.

25. A.C.G. Hotze, J.A. Faiz, N. Mourtzis, G.I. Pascu, P.R.A. Webber, G.J. Clarkson, K. Yannakopoulou, Z. Pikramenou and M.J. Hannon, Dalton Trans., 3025 (2006); https://doi.org/10.1039/b518027a.

26. M. Giurg, S.B. Said, L. Syper and J. Mlochowski, Synth. Commun., 31, 3151 (2001)

https://doi.org/10.1081/SCC-100105891.
27. A.J. Canty, P.R. Traill, B.W. Skelton and A.H. White, Inorg. Chim. Acta, 255, 117 (1997); https://doi.org/10.1016/S0020-1693(96)05357-1.

28. S.M. Couchman, J.M. Dominguez-Vera, J.C. Jeffery, C.A. McKee, S. Nevitt, M. Pohlman, C.M. White and M.D. Ward, Polyhedron, 17, 3550 (1998); https://doi.org/10.1016/S0277-5387(98)00145-4.

29. P. Sengupta, R. Dinda, S. Ghosh and W.S. Sheldrick, Polyhedron, 20, 3349 (2001);

https://doi.org/10.1016/S0277-5387(01)00946-9.

30. T. Chattopadhyay, M. Mukherjee, K.S. Banu, A. Banerjee, E. Suresh, E. Zangrando and D. Das, J. Coord. Chem., 62, 967 (2009); https://doi.org/10.1080/00958970802385837.

31. E. Katsoulakou, N. Lalioti, C.P. Raptopoulou, A. Terzis, E. Manessi-Zoupa and S.P. Perlepes, Inorg. Chem. Commun., 5, 719 (2002); https://doi.org/10.1016/S1387-7003(02)00542-7.

32. S.-M. Yue, H.-B. Xu, J.-F. Ma, Z.-M. Su, Y.-H. Kan and H.-J. Zhang, Polyhedron, 25, 635 (2006); https://doi.org/10.1016/j.poly.2005.07.021.

33. L. Yang, D.R. Powell and R.P. Houser, Dalton Trans., 955 (2007); https://doi.org/10.1039/B617136B. 